\title{
Construction of Social Lives in Ethno-Politically Ruptured Sri Lanka
}

\author{
Anton Piyarathne
}

\begin{abstract}
At the end of the three decade old (ethnic) war, Sri Lankans are slowly but progressively moving towards reconciliation and, perhaps, to finding political solutions to many issues. This progress raises the question of how people from different ethnic and religious backgrounds collaborate when the political and social environment is still vulnerable to tensions and clashes. In order to explore this situation further, I carried out seventeen months of phenomenological research in Sri Lanka, observing many examples of inter-ethnic collaborations. In this article, I describe such everyday collaborations through which I call "commongrounds", a concept I employ to illustrate the ways and means in which the multi-ethnic middle-class community create harmonious social space for everyone to share in ethno-politically volatile Sri Lankan society. I will draw upon insights from Barth, Harrison, Bourdieu and Neofotistos to discuss my research findings on how members of Sri Lanka's middle-class community create everyday relationships based upon their own classifications of "good" and "bad", which cross rigid ethnic boundaries.
\end{abstract}

Index Terms-Ethnicity, nationalism, commongrounds, middle-class, ethnic conflict, Sri Lanka.

\section{INTRODUCTION}

Countries experiencing ethnic tensions are affected by a great variety of integrating and disintegrating forces, a fact evident in discussions centring on political solutions to societal divisions by means of power sharing that have taken place throughout history. The people of Sri Lanka suffered immensely following independence from Britain in 1948. Ethnic tension, violence, fear and intimidation paralysed the development of the country as well as the opportunities of its peoples to enjoy freedom. The 31-year long civil war that ended in May 2009 cost the country not only scores of human lives but resources that should have been disbursed for the eradication of poverty and the improvement of the welfare of the people. Not infrequently, international forums such as the United Nations and associated bodies, along with academic writings, tend to focus upon the elite's political behaviour, peace talks, military action and power sharing models. In other words, the wider world has viewed Sri Lanka as a theatre of violence and bad politics. While films and teleplays have narrated the peoples' suffering to some extent, they have also served as a catharsis rather than initiating broader

Manuscript received September 29, 2013; revised November 5, 2013 This work was supported by the Department of Anthropology Research Fund (2010-2013).

Anton Piyarathne is with the Department of Anthropology, Macquarie University, NSW 2109, Australia and Department of Social Studies, The Open University of Sri Lanka, Nawala, Nugegoda, Sri Lanka (e-mail: anton.piyarathne@mq.edu.au, antonpiyarathne@gmail.com, apiya@ou.ac.lk). movements and social change to eradicate suffering and create peace. Even though the war in Sri Lanka ended in 2009, the influence of divisive nationalist forces, chauvinist ideologies and ethnic politics persist. The government, which is yet to address crucial issues related to ethnic tension, seems unable to come up with lasting solutions. Despite all of the above constraints, it is within this milieu that the people of Sri Lanka must prosecute their everyday social reality.

Although post-independence Sri Lanka saw a lot of politically-motivated tension and a spate of ethnic clashes, a considerable amount of integration prevailed among the members of the various ethnic groups, who mostly lived in heterogeneous communities. They withstood the on-going provocation from various ethno-national and political corners. It was the people's own initiatives that allowed them to enjoy "commongrounds", not the miracles of politicians. In this article I explore how peoples from diverse ethnic backgrounds create environments in which all can live in relative peace. Special reference is made to the middle-class, who resides in the urban area of Sri Lanka's capital city of Colombo.

The above circumstances urged me to carve out a concept called "commongrounds", which I wish to treat as one pragmatic concept although it is written using two words according to English grammatical order. My notion of the concept does not allow social engineers to treat "common" and "grounds" as two separate entities. I approach the notion of "commongrounds" not as a settled state but as a continuing field of struggle similar to Michael Jackson's [1] examination of human well-being in Sierra Leone. I admire the way he employed this static phenomenon in a lively discussion. The Sri Lankan people have had to endure a social life that has required them to cope with a variety of divisive forces, e.g., ethnic-nationalism, chauvinism, religious extremism and ethno-political factions. The nature of the struggle of ordinary people in this volatile political environment has been taken for granted or deliberately not made visible in most academic writings [2]-[4].

In their analyses of ethnic tension in Sri Lanka, scholars including those discussed below, have basically adopted four approaches: primordialist, constructivist, instrumentalist and modernist. Examination of these approaches will facilitate an understanding of the socio-economic and political backdrop to the tension as well as of the approaches. The primordialist approach discusses language, religion, and culture in relation to the conflicting ethnicities and nationalism [5]-[6]. Advocates of this approach tend to argue that historical factors, in particular the age-old Sinhala/Tamil rivalry, can explain the on-going conflict. However, I will suggest that the explanations put forward are weak if not incorrect. 
History shows that Sinhalas and Tamils have shown a propensity for an extensive, peaceful co-existence for more than a millennium. So, why do they engage in conflict now?

Researchers including Tambiah and Daniel [7] have highlighted the constructivist approach. A careful reading of works by Arasaratnam [8]; De Silva [9]; Makenthiran [10]; Orjuela [11] and many others indicates that authors who have tried to establish, confirm or reiterate ethnic divisions and tensions in society, appear to have quite conveniently either overlooked or taken for granted any peaceful coexistence or complexities which exist amidst tension. Tambiah, for example, points out three types of differences persisted in the pre-colonial period, e.g., caste, geographical and communal aggregates. In effect, these differences are not ethnic divisions. During the Portuguese and Dutch colonisation of Sri Lanka (1505-1796), while people were divided on the basis of caste, they were increasingly enumerated and aggregated according to the Sinhala caste structure: Karāwa (fishing), Salāgama (cinnamon peelers) and Tamil castes; Vellāla, Karaiyār and Mukkuvār (matrilineal Tamil caste). Even today, there are intra-ethnic variations among the Sinhala, Tamil and Muslim peoples of Sri Lanka. Tamils are not an homogenous community: they have different identities such as Colombo, Batticaloa, Jaffna and Plantation [12], [13]. The Sinhalas and Muslims are also no exception to this rule.

Instrumentalist theory attempts to explain the role of the elites - and of rational choice exercised by the people - in the creation of conflict. This, in my mind, is by far the best theory for explaining the causes of ethnic conflict. The argument proposed in this theory is that making Sinhala the official language, and the practice of that language in the country's offices and schools for over two decades contributed to the marginalisation of the non-Sinhala who in turn lost confidence in the government and isolated them from Sri Lanka's poly-ethnic society in general. DeVotta [14] sees the Sri Lankan conflict as an ethno-national struggle sparked by ethnocentric practices initiated by the state and/or the majority Sinhala people. But, while these may be good observations, the instrumentalist theory not only fails to explain all of the factors that underpin Sri Lanka's ethnic tension: it fails to explicate how on-going peace can be achieved.

Modernisation theorists assume that when the colony became independent, people became less influenced by their traditional, ethnic and religious allegiances due to the enlightening influences of modern education, media, state formation, democratisation, capitalism and the intellectualisation of culture. As far as the people were concerned, these modern traditions, it was assumed, would support broader identity development and diminish their tendency to align with parochial identities [14], [15]. But, this did not occur as anticipated: Sri Lanka's minority ethnic groups felt that not only had they been excluded from development; they had been deprived of any chances for a good life [16], [17].

My research findings, which aim to shed light on the above, are based upon my fieldwork observations and careful literature study. My review of the extant literature suggests that the politicization of ethnicity and ethnic relations has contributed significantly to the tension that destabilizes the country today [18]. The prevailing situation warrants a constructivist approach from a broader perspective, perhaps borrowing from the instrumentalist and modernist approaches. The aim of this article is to discuss commongrounds in connection with a middle-class settlement that constitutes part of my broader research in four locations in Sri Lanka.

\section{BOUNDARIES AND THEIR LIMITS}

In any discussion of commongrounds, the actors' efforts to negotiate ethnic boundaries should feature at the forefront. Anthropologist Fredrik Barth [19] is noted for changing the discourse of ethnicity from a static notion of difference to an interactional phenomenon. Barth's approach has three core principles: first, he identifies ethnic groups as categories of attribution and recognition by the actors themselves. According to this proposition, ethnicity plays a role in organising interaction between people; second, he discusses the diverse methods of producing and retaining ethnic groups; and third, in an attempt to facilitate an understanding of the ethnic boundary-making process, he shifts the existing paradigm studying the internal characteristics and history of ethnic groups to ethnic boundaries and boundary creation.

Barth's recognition of cultural traits serving as ethnic boundaries, which is not exactly practical in the Sri Lankan context, was debated at the conference on "The Anthropology of Ethnicity" convened in Amsterdam in December 1993. The resultant publication titled The Anthropology of Ethnicity: Beyond 'Ethnic Groups and Boundaries' (1994) drew a threefold link between culture and ethnicity: 'Ethnicity refers to the consciousness of (ethnic) culture, to the use of culture, and at the same time is part of culture' [20]. First, apropos of the final point, Barth depicts ethnicity as an element of social organisation to be considered as part of culture. Anthony P. Cohen [21] claims that while boundaries can be seen in 'interactional terms', they can similarly be regarded as 'boundaries of consciousness'. Second, in effect, it may be that ethnic identities are the outcome of 'classification, ascription and self-ascription and bound up with ideologies of descent' [22]. In this sense, inquiry into ethnicity is connected to the study of 'ideology and of cognitive systems' from which standpoint it becomes part of culture. Ethnicity may from particular perspectives be considered as 'meta-cultural' because it is often a manifestation of 'what our and their culture is about'. Third, the term 'ethnicity' implies 'the subjective, symbolic or emblematic use by a group of people of any aspect of culture, in order to differentiate themselves from other groups' [22].

Barth [23] later stressed the situational nature of boundary-making as opposed to the more static notion of cultural boundary-making he proposed in the late 1960s. The notion of situational ethnicity has since been widely debated, mostly by social anthropologists. Barth highlighted the nature of culture as varied, constantly in flux, contradictory, incoherent from place to place, and as different in variously-positioned persons. Moreover, the survival of culture could be further varied in accordance with the ways in which a particular culture evolves within a community. 
Verdery [24], arguing in support of Fredrik Barth, endorsed the notion of situationalism that gained widespread acceptance by 1970 s anthropology following publication of Barth's Ethnic Groups and Boundaries. According to Verdery, the most influential examples of situationalism came from the 'Third World' rather than the 'First World'. However, the state-making processes of a country impact upon the ways in which ethnic identities are shaped. The usage of majoritarian democracy in Sri Lanka resulted in more representation of the Sinhalas, an outcome considered unfortunate by the ethnic minorities who organised their ethnic politics accordingly. This does not mean that the consolidation of modern nation states eliminates situational manipulation of identities altogether: it is possible that such manipulation also occurs in micro-interactions.

Verdery [24] suggests that Barth did not mean to imply that culture necessarily works as an ethnic boundary established to block inter-ethnic relations when he posed the question: 'How [can] culture ... be integrated and/or shared to varying degrees'. According to Verdery, Barth's position was 'that transactions across ethnic lines were possible with only the most minimal sharing of evaluative principles, and he showed that this minimal agreement was nonetheless sufficient to sustain interaction despite massive disagreements between interacting groups' [24]. This discussion validates my argument against the blanket, divisive ethnic identities often projected in the ethnic conflict discourse in Sri Lanka. Perhaps, the situational ethnicity appearing in various places in Sri Lanka can be reckoned as a form of commongrounds created as a way of dealing with divisive ethno-nationalist forces.

Verdery's comments regarding the usage of ethnicity as a way of achieving political power and holding it summarises the long story of tense ethnic relations in Sri Lanka. She presents concepts such as ethnicity, nationalism, state and identity user friendly. Differences develop into politically important issues because ethnicity and culture are seen as the locus of homogenization, rendering groups visible as ethnically different. 'These connections also encompass both nationalism and the notion of identity' [24]. Ethnicity and nationalism are closely related social ideologies, social classifications based on the assumption of certain types of differences.

Despite the fact that the concept of situational and contextual ethnicity may have some validity in Sri Lanka, the inappropriateness of considering culture as an ethnic boundary is noted by Harrison [25], who argues that cultural difference is denied resemblance. In general, ethnicity and nation are defined by their dissimilarities, e.g., the cultures, histories, mentalities and bodily appearance imagined or perceived to exist between self and others. While he recognizes Fredrik Barth as one of the first researchers to use this approach, he does not agree with Barth's proposal to use symbols of cultural dissimilarities to create social boundaries and shape connections across said boundaries. He further contends that the suggestion that cultural categories are created negatively to create ethnic boundaries has no 'intrinsic content' [25]. The defining of ethnicity and nation from this traditional perspective creates 'marginalized others' evoking them to form oppositional identities and mobilising themselves through resistance. According to Harrison, certain features of ethnic and national identities remain puzzling according to this kind of approach: conceptualising ethnicity and nationalism as relationships will help to explain denied or disguised resemblance rather than emphasising differences or sensed differences as Barth often did.

While Harrison's approach urges me to discuss cultural cooperation, Neofotistos [26] affords me the possibility of understanding inter-ethnic connections pragmatically. He shows the possibility of the co-existence of tension and peace in a given society. He also considers the possibility of local actors deeming ethnic boundaries porous and incorporating individuals of different ethnic origin within their communities by employing classificatory principles.

Using the term 'classification' in the following practical sense that helps to explain commonground, Neofotistos [26] suggests that scholars including Handler (1988) and Herzfeld (1992), among others, proposed 'stereotypes' that could be considered a means by which local actors could 'sort out' and 'justify' their 'classification' of the rest of 'the world' at a 'particular moment', stereotyping that performs a significant function in the negotiation of ethnic identity. Simultaneously, he also argues that the porousness of ethnic boundaries can similarly signal the ways in which actors understand social worlds and their respective positions in it [26].

Neofotistos sheds light on how inter-ethnic relations may be negotiated in everyday life in a society tagged with negative ethnic stereotypes and vulnerable to ethnic violence. Members of one ethnic group work with ethnic 'others' in accordance with their own social classifications to create 'inclusive social arenas' in practice. These alternative classifications are based on culture rather than ethnicity, which tends to divide people rather than unite them. Culture underpins the 'state of civilization' linked to the ideal of European identity and the 'civilization' linked with 'urban way of life'. Such a civilised state can be reached via the extension of 'good manners towards friends and neighbours, refined social behaviour, respect and consideration, [and] openness and willingness to communicate' [26].

My argument pertaining to commongrounds is acknowledged by both Barth's and Verdery's situational nature of ethnic identity. But, I draw greatly upon Harrison's discussion of cultural resemblance to discuss interethnic relations by way of ethnic boundary negotiation. I employ Neofotistos' notion of local actors creating alternative classifications to illustrate how members of middle-class communities develop relationships despite the prevailing ethnic divisive trends in the broader socio-political environment of Sri Lanka.

\section{A PHENOMENOLOGY OF BOUNDARIES}

Barth suggests that anthropologists must pay attention to the experience through which an ethnic identity is formed in order to comprehend complex and subtle ethnic border negotiation. I personally attempt to do this here using a phenomenological methodology to study commongrounds building in a so called ethnically volatile Sri Lanka. In this research, I have employed person, event and 
discursive-centred ethnographies assembled during more than Seventeen months of fieldwork started in October 2010. This is similar to the approach adopted by Mattingly [27] for his monograph entitled The Paradox of Hope. My main access to the community was facilitated by a voluntary community organisation known as the Beach Park Management Society (BPMS), established in 2005. The main field of study in this research comprises ethnographies of networks similarly discussed by Herzfeld [28]. Studying these networks gave me the opportunity to comprehend the shape of interethnic relations in Sri Lanka and the situations in which they occurred. I gradually developed connections with members of the BPMS and looked at their (family) connections along with others of the community.

\section{PROCESS OF COMMONGROUNDS BUILDING}

Crow Island (Kakka Dūwa or Kakkadupatha in Sinhala: Kakkatheewu in Tamil) is a small island community bordered by the Keleani Ganga (Kelani River) on one side and the two kilometres long Vystwyke canal - that separates the community from the mainland and the Indian Ocean - on the other. This research site is located in the north of Colombo, an ethnically-mixed Mattakkuliya area in which approximately seven hundred housing units accommodate the Sinhala, Tamil and Muslim peoples who populate the Island [29]. This multi-religious neighbourhood has a Kovil (Hindu temple), a Mosque, a Buddhist temple, a Catholic Church, and is host to some Christian missionaries. Crow Island was previously home to low-income dwellers who lived in the island's slum area before the 1980s. Later, they were evicted by R. Premadasa, then Minister of Housing and Construction, to create middle-class housing schemes through joint ventures with some foreign investors. Today, these houses, which are joint units built either side of the island's by-lanes, are home to a heterogeneous community who live in very close physical proximity. The middle-class symbols of Sri Lankan standards are highly evident in this area; houses are surrounded by high walls, the gates have bells, and one sees various notices such as "no parking", "private road", "beware of dogs" and security guards at the entrances to the by-lanes or houses. Most of the residents have very busy life schedules and are hard put to find leisure time to discuss local issues, even with their neighbours.

The Crow Islanders put into effect their own autochthonous scheme of classification to smooth their interaction with ethnic others and mitigate stigmatising labels. The classification identifies two groups of people: "good" (or "compatible") and "bad" (or "incompatible"). The "good" persons are identified as honda in Sinhala or ottu pōrawanga in Tamil while the "bad" people are identified using local terminologies, i.e., naraka, harinahe or nogalapena in Sinhala and ottu pōwadawanga in Tamil. Almost all of the middle-class Crow Islanders appeared to be "good" people. Their classificatory system is applied not only to the area's different ethnic groups but also to intra-ethnic groups. For example, Crow Island is home to different sub-Tamil groups including Indian Tamils, Sri Lankan (or Jaffna) Tamils, Batticaloan Tamils and Colombo Tamils, ethnic groups that are commonly seen as experiencing difficulty getting along.
The above categorisation, based on their common middle-class backgrounds, has allowed the various ethnic groups to maintain riskless relationships as friends and neighbours and ultimately to unite as Crow Islanders. Together, they symbolise a middle-class way of life, worldview and recreational pattern, all of which combine to construct the "culture" of Crow Island facilitated by Roosen's critique of Barth: Boundaries may construct identities not essentially ethnic identities [30].

I would like to pay special attention to a situational manifestation of ethnicity here, Bourdieu's middle-class or petite bourgeoisie [31] when discussing commongrounds. Bourdieu's discussion of "taste" suggests that people become acculturated in accordance with their social position. In other words, they develop special likings or dispositions that distinguish middle-class people, a premise that I will employ throughout the discussion. Bourdieu's notion of "habitus" summarises the ways in which taste and dispositions are communicated and embodied. Bourdieu's discussion of the middle-class focuses on three important aspects: "The role of culture as a set of differentiated 'tastes' and socialisation as a set of consciously differentiating practices; the importance of everyday practices; and the different kinds of capital available to the middle-class" [32]. He recognises that economic, cultural and social capital create middle-class subjectivities and lifestyles, through which Sri Lankan inter-ethnic unity building is possible. Bourdieu's insights into sports, leisure, social class and social capital will be drawn upon to examine the activities of the BPMS and how they involve the multi-ethnic Crow Islanders. Rather than assuming a kind of universal importance of ethnicity, Sandra Wallman [33] emphasises that we should consider the context in which ethnic identifications take shape. For the middle-class residents of Crow Island, I suggest that class consciousness often invalidates or decreases the power of ethnicity because it deemphasises the need to identify to which group one belongs or not.

The Crow Islanders, whose occupation backgrounds vary from those of their counterparts in neighbouring communities, enjoy a unique lifestyle shaped by their middle-class socio-economic milieu. At the same time, their livelihoods show some similarities in terms of social prestige and level of income. They engage in business (jewellery, hardware, steel, stationery, customs clearance), are currently serving or have served in government departments, as accountants, teachers, consultants, and as various top jobholders in private sector companies. As well, some constitute the middle level self-employed (e.g., electricians, electronic items repairers, and boutique proprietors). They often use their own vehicles or hired vehicles to commute: most have experienced foreign exposure or have foreign connections. As a community, they are both enlightened and sensitive about changing the socio-political environment, a topic they have discussed with various local and international media. Their trilingual capacity (Sinhala, Tamil and English: they mix the latter with 'swabasha' (Tamil or Sinhala) in the home) has enhanced their worldview and social understanding. In the mornings or evenings, some among them go to the beach to do physical exercise and it is here that they form friendships with others. All other classifications 
happen within this broader commongrounds. This is how people become distinguished as Crow Islanders; "we are Crow Islanders". We represent a united Crow Island. Identification as a Crow Islander - as distinct from a non-Crow Islander - is in itself a way of inclusion of a group of persons not on the basis of ethnicity but through a shared middle-class social status.

This situation is clearly evidenced in the everyday attitudes of the Crow Islanders towards a number of war refugees living in a camp on the island. The Islanders do not consider the refugees - a group of Muslim Internally Displaced People (IDP) forcibly evicted by the LTTE from their homes in Jaffna, Mannar, Vavuniya as a measure of creating a pure ethnic Tamil regime called Eelam in the 1990s - as part of their community.

It appeared that the middle-class Crow Islanders preferred to gather through formal bodies such as the LKN Housing Scheme Society and/or the Sea Breeze Garden Housing Scheme Society (SBGHSS). In addition, they had access to other formal associations; the Crow Island Housing Scheme Welfare Society (CHSWS), Hindu Society, Catholic Society, Buddhist Dayaka Sabha and the Mothers Union, all of which were very active in addressing the welfare of the dwellers. My main observation took place in the BPMS, which included residents of Crow Island who also held membership of the other associations mentioned above. The main objective of the BPMS from the time of its inception in 2005, has been to create and maintain the beautiful beach. Implicit in their objective has been community participation, the enhancement of inter-personal relationships and cooperation among the daily beach users, and, finally, the development of a community consciousness. In general, everyone with whom I associated equally believed that they had become very close and developed a bond after starting to work at the BPMS. The executive committee and board of members are elected every year at the Annual General Meeting. There were approximately 140 general memberships mainly drawn from Crow Island at the time the research was conducted. Within this organization, the heterogeneous members conduct various activities in line with the above objectives, e.g., the Sinhala-Tamil New Year festival, poson dansala (an outlet where foods and drinks are served freely with the expectation of merit. Buddhists organise these outlets around the country during activities such as religious festivals (wesak and poson, for example)), beach beautification projects, Crow Island cleaning, dengue fever-prevention programmes, get-together parties including 31st night dinner parties, and arranging picnics.

They join together to engage in Shramadana (gift of labour) programmes and to clean the beach on Poya days (full moon day, a public holiday in Sri Lanka). Everyone makes sure that they attend Shramadana after morning jogging: some members voluntarily provide food for all of the participants. At such gatherings, ethnic differences are forgotten: no-one shows concern about the ethnic background of the person who provides the food and drinks: all partake of them happily. They are committed to doing Shramadana as part of their social responsibility. During the weekends, thousands of people living in the Colombo North area come to the beach to enjoy it with their families. During
Shramadana, the members clean up the garbage left behind by those who visit during weekends: in the process, they discuss further development, crack jokes, and share family matters and business-related issues with other members.

The ethos of the BPMS was developed in a manner that ensured that no one was hurt and all members are given due respect. No one's ideas and suggestions were suppressed or looked down upon dismissively. Everyone is equal in the association. I was never aware of any instances when members argued about or quarrelled during debates about association activities. They individually contributed and committed to the welfare of the community. The BPMS has helped the Crow Island society in many ways. They have gradually eased the restricted access to the beach and the security tightening imposed with the establishment of a naval base close to the mouth of the Kelani Ganga (river) during the war. Furthermore, the BPMS has been actively involved in the development of welfare and recreational facilities on Crow Island.

The beach area, a strip of Crow Island land which is managed by the BPMS, is in itself a common space for diverse groups of people; i.e., men-women, young-old, lovers- married- divorced, Buddhists- Hindus- ChristiansIslamists, and, finally, Sinhala-Tamil-Muslims. Two parks for children, which were covered with barbed wire and provided exclusive access for children, had child-oriented facilities that attracted more families to the beach (as well as the regular facilities for visitors). There were benches provided where people could sit and talk, an open stage used for various functions, lampposts erected, garbage bins albeit rarely used, and a lavatory. Mobile ice-cream sales outlets and short eat sellers from heterogeneous backgrounds had set up their businesses. Some young people provided exciting, fee levying horse and cart rides along the beach.

I moved amongst the thousands of Sinhala, Tamil and Muslim people, who experienced jam-packed lifestyles in the City of Colombo during the week and had come to the beach to relax over the weekend. Families clearly loved to sit on the grass and talk and play with their children in the evenings. Young people were eager to play cricket, "a game everyone likes" in Sri Lanka. Lovers from a wide range of ethnic backgrounds came to visit the beach: some families went swimming. This common space was very lively although it often appeared to be a silent zone. I met a study group comprising a German man, a Buddhist Sinhala man, a Christian Tamil man, and a Muslim. They questioned the existence of a god sitting on the granite blocks that had been erected as a barrier to prevent sea erosion. This beach is commonly used by Hindus to release the ashes of dead family members into the sea, commemorate rituals such as $\bar{A} d i$ Amavasai (a day sacred to obsequies for the manes, a Hindu ceremony to celebrate parents who have passed away), for healing rituals and other kovil-related rituals. I noted some Muslims taking sea-sand for various rituals.

I observed a group of people exercising together on the beach from 4.30 a.m. to 9.00 a.m. and in the evenings after 4.00 p.m. Most of the group members I met at the beach claimed a history of exercising for more than ten years while some had been using the beach for more than 20 years. People greet each other and associated heterogeneous 
neighbours with "good morning, how are you?" (in English). By becoming a regular member of the morning joggers I gained access to their social worlds. During these sessions, they shared information with colleagues representative of other fields. I saw Tamil and Muslim friends in consultation about their legal issues with a Sinhala lawyer, a Muslim Municipal Councillor often meeting with a retired senior police officer, a Sinhala lady inquiring about the gold market from a Tamil jeweller and others discussing issues common to the city life. As well, I met many groups discussing personal, sporting and socio-political issues.

Bourdieu [34] observes that associations such as the BPMS, established by professionals and the bourgeoisie in the interests of sport - which is connected to the physical exercise of the beach users - link social functions such as dinners, get-togethers and musical shows, for example, through which they can accumulate social capital. The BPMS itself organises end of year get-togethers to which family members of the association are also invited. I took part twice in such gatherings. Members of the BPMS conducted the 2011 New Year's celebration along with the LKN society, which is headed by a very active member of the BPMS. Not only this person but most of the members of the LKN society hold membership of the BPMS as well. They constitute one group of people represented in various forms. The BPMS members made a significant contribution to hosting this celebration on a grand scale. The music group, formed by a member of the BPMS, provided Sinhala, Tamil, English and Hindi music which the participants enjoyed immensely. A dancing team of Sinhala girls trained by a Buddhist Sinhala dancing teacher from the BPMS performed an upcountry dance. There was an ample supply of soft and hard drinks and food for people to enjoy. I experienced the associates of BPMS's concern over the people they hoped to link with by participating in the 2011 annual picnic. It involved a one-day trip to visit Maduganga estuary in Aluthgama, which is located a 3-4 hour drive from Colombo. On the day of the picnic, the participants enjoyed a boat trip, music, dancing and a variety of local food. So, not only did they have more time to share various aspects of their lives with their fellows but the event enhanced the understanding each had for the other and strengthened their bonds.

I met some ethnically mixed families among the members of the BPMS. I noted both a Sinhala-Tamil mix and a Muslim-Burgher mix. During our discussions, the respondents recounted stories of members of their extended families marrying ethnic others. Religious mixing is a common phenomenon among these families. During the narratives, what was commonly imparted was that the respective families looked at the broader qualities that can determine "good" and "bad" characteristics. Deepika, a Buddhist Sinhala lady married to Hindu Tamil Krishnan Sundaralingam, first met Sundaralingam when he was boarding with one of her distant relatives. When their love affair came to the attention of the parents of both parties, the former opted to negotiate the ethnic border through other qualities. In Deepika's parents' eyes, Sundaralingam was a "good" young person - "a non-drinker", "non-smoking", "well mannered", "educated", and "working hard to get self-improved" characteristics. I met the couple at the beach on Crow Island during jogging sessions every morning. They visit both kovils and Buddhist temples and are a very good family in the eyes of the Crow Islanders.

The friendships and bonds developed through the BPMS spread throughout various other areas of community life: members tend to interact with colleagues outside of the BPMS. Members are invited to homecoming parties, weddings, coming-of-age ceremonies and to other happy occasions as well: they are also included on sad occasions such as funerals. Once when a Burgher-Christian member of the association underwent bypass surgery, all of the members became very concerned: they conducted rituals according to their own religious tenets wishing their friend a quick recovery. One Tamil-Christian member of the association organised an at-home party to which he invited most of the members of the association. Some smaller groups, who have developed friendly relations, arrange special trips to see friends who live elsewhere in the country or to picnics.

The companionships that develop through the BPMS urge members to participate in the religious activities of "friends" from other religious and ethnic backgrounds. They may contribute in the forms of cash and miscellaneous items. I met Gajenthiran, a 45 years old Hindu Tamil man, while he was decorating the chariot for the Buddhist Katina Procession towards the end of 2010. He claimed that he decorated the chariot annually free of charge, a service I witnessed again in 2011. He also performed a Kolam dance, masquerading as a devil in the procession. The Buddhist priest who officiated at the temple highlighted this as a fine example of the existing unity in the community. When Gajenthiran was 13 years old, he went to India with his family members as a refugee of 1983 ethnic riots: he stayed in a camp for approximately eight years, during which time he suffered a lot. His parents had gone to India with no hope of returning after selling their house and all of their properties in Nuwara Eliya. His elder brother, who was working as a sales assistant in a wholesale shop in Colombo, feared for his life when thugs launched an arson attack on the shop, which was owned by a Jaffna Tamil person. However, five years' experience of India was enough to convince his parents of the value of their home country; so, they returned. He selected Crow Island as a place to settle permanently when he obtained a house as seethanam (dowry). Nowadays, Gajenthiran, a Hindu Tamil person of Indian origin, speaks of himself as a "Colombo Tamil" married to "Jaffna Tamil" wife, who both popularly claim to be "Colombo Tamil". His brother, who was working as a sales assistant when his shop was attacked, has since become the owner of the very shop that was burnt in the riots. He also married a Sinhala-Buddhist lady from Colombo. Similar to Gajenthiran, I met Muslim and Christian members of the community attending ceremonies at the Buddhist temple.

In general, the Crow Islanders support and tolerate diverse religious activities. The annual processions, i.e., the Sri Ambal Hindu Kovil, the Katina Procession of the Buddhist temple, and mother Mary's procession of the Catholic Church could not be held without the support of the community. Residents come out of their houses to view the processions, and to receive the blessings of the gods and goddesses. I was able to witness the warm friendships and cooperation that transcend ethnic borders during these 
festival times. In general, the Sri Lankan milieu comprises a religious mix: Buddhists visit Hindu kovils, Tamils visit Buddhist temples, and Hindus and Buddhists visit Christian churches. Muslims, who contribute to functions organised by other religious institutions, also come to see the processions. The Crow Islanders often become concerned about the rights of others when the various religious activities are performed.

The Crow Islanders also maintain good relationships based on the classifications alluded to above with non-members of the BPMS. My discussions and long-term associations with members of the BPMS, often as a guest in their homes, illustrated details of inter-family relationships based on the above classificatory scheme. One Tamil-Christian person always seeks the support of the Buddhist Sinhala trader who lives in the front house to care for his house and property during his absence; he buys goods from this traders' shop, share plates of food and sweets during festivals, and to visit if either one becomes ill. This Tamil friend, with his Indian origin Tamil background, always looks after a Jaffna Tamil old lady, a teacher who lives alone in a neighbouring house. In general, it is the intra-ethnic identities that have difficulty interacting each other. Similar to a few other teachers, the above old lady provides English tuition for the Sinhala, Tamil and Muslim children of the Island, a situation I observed in other families as well. I have seen some residents, who invite neighbours for dinner or lunch during festivals, and women enjoying seettu dameema (casting lots, local microfinance activity) with a group of neighbours, send their children for tuition from educated neighbours who run tuition classes. Crow Islanders buy their essential foodstuffs from shops run by people from Sinhala, Tamil and Muslim backgrounds. Over time, these regular business relations will also be converted into a bond.

The members from middle-class backgrounds also interact with ethnic others who represent different social classes as well. I was told by a Hindu Tamil, Jaffna man that a Christian Sinhala man, who has no-one to look after him, sleeps and eats at his house. When this gentleman is away, maybe goes to India for medical treatment or to Jaffna to check on his property, the Sinhala man looks after his house. Crow Islanders use the "good" and "bad" category when they get the services from heterogeneous members living outside of the community. Members of a friendly Tamil family often hire a Muslim person's three-wheeler to drop their child at school: another Muslim family may buy fish from a Sinhala fishmonger; a Sinhala family may use masons and carpenters from Tamil backgrounds.

The Crow Islanders may be seen as a selected category of people who have achieved relatively good education, social exposure, engaged with respectable jobs which have assured them a decent income, and have contributed to an individualist life with a degree of self-dignity. This background has afforded the residents trouble free lives and freedom from possible conflict with neighbours. This does not mean that the Crow Islanders do not experience tension. In the event that confusion arises with neighbours they prefer to negotiate failing which they will seek the help of police and the judicial system. One Muslim and one Jaffna Tamil member of the BPMS found themselves in an uncomfortable situation over the falling of dried coconuts and branches. The problem was sorted out through mediation with the police.

My association with members of the above heterogeneous community convinced me that they owe themselves continuation of the extant, stable, social system, which entails cooperative and friendly relations. This may be considered a way of life in the sense of habitus proposed by Bourdieu [35]. Furthermore, I noted that every newcomer to the society gradually absorbed this social system as a way of replacing outer migrants from the society. I observed that the collaboration that obtains between adults is gradually transferred to the sons and daughters as well. I noticed on many occasions parents accompanying their children to participate in Shramadana campaigns, Sinhala-Tamil New Year festival and many other events.

\section{CONCLUSION}

My long-term period of fieldwork on Crow Island revealed that the residents' middle-class consciousness has facilitated them to negotiate ethnic boundaries and unity building despite the polarisation trends in the country. The study also proved the less rigid situational ethnicity in the sense explained by Barth and further elaborated by Verdery. Their unique, middle-class lifestyles, educational backgrounds, modern lifestyles shaped by their livelihoods and non-dependability have lessened the possibility of always wearing ethnic lenses. Their classification of the community based on particular unique qualities alluded to by Neofotistos; i.e., Honda or Ottu Pōrawanga (good) and Naraka, Harinahe or Ottu Pōwadawanga (bad) has underpinned the creation of commongrounds receptive to integration with ethnic others. This classificatory scheme has stood the test of time from the inception of the island by exposing it to ethnic tension and ethnic politics and also to the civil war situation. Coming together in formal bodies such as the BPMS has facilitated a means of developing inter-subjective understanding and relationship building. The BPMS, a non-ethnic, non-religious entity instituted to improve the facilities for the members of the community, now acts as a hub of social networks. The efforts of this association can also be enjoyed by members of the working class and/or peoples from shanty and low income areas. They too may access this middle-class social construction of "relaxation", "happiness" by way of children parks, benches arranged for visitors, garbage bins kept for proper utilisation by the beachgoers and the installation of a security unit to assure their safety. This formal body, which was initiated by a group of joggers, who met regularly on their morning runs, has both developed and extended to other sectors of the Crow Islanders' social lives. The friendly interaction among this heterogeneous community can be understood as habitus explained by Bourdieu. There is no uncertainty regarding 'professions' and 'well established business bourgeoisies' combining 'health giving' and 'aesthetic functions' with 'social functions' where sports joins with social exchanges such as receptions and dinner parties which accumulate social capital. 


\section{REFERENCES}

[1] M. Jackson, Life Within Limits: Well-being in a World of Want, Durham: Duke University Press, 2011, pp. ix-xiii.

[2] S. J. Tambiah, Sri Lanka: Ethnic Fratricide and the Dismantling of Democracy, London: I. B. Tauris, 1986, pp. 1-114.

[3] S. J. Tambiah, Leveling Crowds: Ethnonationalist Conflicts and Collective Violence in South Asia, Berkeley: University of California Press, 1996, pp. 3-101.

[4] S. J. Tambiah, "Urban riots and cricket in South Asia: a postscript to 'Leveling Crowds'," Modern Asian Studies, vol. 39, no. 4, pp. 897-927, October 2005.

[5] A. R. M. Imtiyaz, "The Eastern Muslims of Sri Lanka: special problems and solutions," Journal of Asian \& African Studies, vol. 44, no. 4, pp. 407-427, July 2009.

[6] A. R. M. Imtiyaz and B. Stavis, "Ethno-political conflict in Sri Lanka," Journal of Third World Studies, vol. 25, no. 2, pp. 135-152, Fall 2008.

[7] E. V. Daniel, Charred Lullabies: Chapters in an Anthropography of Violence, Princeton: Princeton University Press, 1996, pp. 3-153.

[8] S. Arasaratnam, "Nationalism in Sri Lanka and the Tamils," in Sri Lanka: Collective Identities Revisited, M. Roberts, Ed. Colombo: Marga Institute, 1998, vol. II, pp. 295-313.

[9] K. M. D. Silva, Managing Ethnic Tensions in Multi-ethnic Societies: Sri Lanka 1880-1985, London: University Press of America, 1986, pp. 1-158.

[10] S. Makenthiran, Tamils in Independent Ceylon: A History of Tamil Struggle for Survival, Canada: Author's publication, 2003, pp. 1-87.

[11] C. Orjuela, "The bullet in the living room: linking security and development in a Colombo neighbourhood," Security Dialogue, vol. 41 , no. 1, pp. 99-120, February 2010.

[12] J. Schrijvers, "Fighters, victims and survivors: construction of ethnicity, gender and refugeeness among Tamils in Sri Lanka," Journal of Refugee Studies, vol. 12, no. 3, pp. 307-333, September 1999.

[13] A. J. Wilson, "The Colombo Man, the Jaffna Man, and the Batticaloa Man: regional identities and the rise of the Federal Party," in The Sri Lankan Tamils: Ethnicity and Identity, C. Manogaran and B. Pfaffenberger, Ed. Colorado: Westview Press, 1994, pp. 126-143.

[14] N. Devotta, Blowback: Linguistic Nationalism, Institutional Decay, and Ethnic Conflict in Sri Lanka, California: Sage, 2004.

[15] G. Delanty and P. O'Mahony, Nationalism and Social Theory: Modernity and the Recalcitrance of the Nation, London: Sage, 2002, pp. 1-119.

[16] E. Nissan and R. L. Stirrat, "The generation of communal identities," in Sri Lanka: History and the Roots of Conflict, J. Spencer, Ed. London: Routledge, 1990, pp. 19-44.

[17] J. Schrijvers, "Internal refugees in Sri Lanka: the interplay of ethnicity and gender," European Journal of Development Research, vol. 9, no. 2, pp.62-82, December 1997.

[18] J. Spencer, "A nation 'living in different places': notes on the impossible work of purification in post-colonial Sri Lanka," in Migration, Modernity and Social Transformation in South Asia, F. Osella and K. Gardner, Eds. London: Sage, 2004, pp. 1-24.

[19] F. Barth, "Introduction," in Ethnic Groups and Boundaries: The Social Organization of Cultural Difference, F. Barth, Ed. Bergen-Oslo: Universitets Forlaget, 1969, pp. 9-38.

[20] H. Vermeulen and C. Govers, "Introduction," in the Anthropology of Ethnicity: "Beyond Ethnic Groups and Boundaries," H. Vermeulen and C. Govers, Eds. Amsterdam: Het Spinhuis, 1994, pp. 3.

[21] A. P. Cohen, "Boundaries of consciousness, consciousness of boundaries: critical question for anthropology," in The Anthropology of Ethnicity: "Beyond Ethnic Groups and Boundaries," H. Vermeulen and C. Govers, Eds. Amsterdam: Het Spinhuis, 1994, pp. 59-79.

[22] H. Vermeulen and C. Govers, "Introduction," in the Anthropology of Ethnicity: "Beyond Ethnic Groups and Boundaries," H. Vermeulen and C. Govers, Eds. Amsterdam: Het Spinhuis, 1994, pp. 4.

[23] F. Barth, "Enduring and emerging issues in the analysis of ethnicity," in the Anthropology of Ethnicity: Beyond "Ethnic Groups and
Boundaries," H. Vermeulen and C. Govers, Ed. Amsterdam: Het Spinhuis, 1994, pp. 11-32.

[24] K. Verdery, "Ethnicity, nationalism, and state-making-ethnic groups and boundaries: past future," in The Anthropology of Ethnicity: Beyond "Ethnic Groups and Boundaries," H. Vermeulen and C. Govers, Ed. Amsterdam: Het Spinhuis, 1994, pp. 33-58.

[25] S. Harrison, "Cultural difference as denied resemblance: reconsidering nationalism and ethnicity," Comparative Studies in Society and History, vol. 45, no. 3, pp. 343-361, April 2003.

[26] V. Neofotistos, "Beyond stereotypes: violence and the porousness of ethnic boundaries in the Republic of Macedonia," History and Anthropology, vol. 15, no. 1, pp. 47-67, 2004

[27] C. Mattingly, The Paradox of Hope: Journeys through a Clinical Borderland, Berkeley: University of California Press, 2010, pp. 1-36.

[28] M. Herzfeld, Anthropology: Theoretical Practice in Culture and Society, Malden, Mass: Blackwell, 2001, pp. 133-151.

[29] C. A. Wijeyeweere. (August 2011). Quick action in development: pilot project in Crow Island, a cosmopolitan island as a learning process. Daily News. [Online]. pp. 8-16. Available: http://www.fccisl.lk/files/media/new\%20alerts/en/2011/August\%207, $\% 202011 . p d f$

[30] E. Roosens, "The primordial nature of origins in migrant ethnicity," in The Anthropology of Ethnicity: "Beyond Ethnic Groups and Boundaries," H. Vermeulen and C. Govers, Eds. Amsterdam: Het Spinhuis, 1994, pp. 81-104.

[31] P. Bourdieu, Distinction: A Social Critique of the Judgement of Taste, London: Routledge \& Kegan Paul, 1984, pp. 257-371.

[32] H. Donner and G. D. Neve, "Introduction," in being Middle-Class in India: A Way of Life, H. Donner, Ed. London; Routledge, 2011, pp. $1-22$.

[33] S. Wallman, "Ethnicity and the boundary process in context," in Theories of Race and Ethnic Relations, J. Rex and D. Mason, Eds. Cambridge: Cambridge University Press, 1986, pp. 226-245.

[34] P. Bourdieu, "Sport and social class," in Rethinking Popular Culture: Contemporary Perspectives in Cultural Studies, C. Mukerji and M. Schudson, Eds. Berkeley: University of California Press, 1991, pp. 357-373.

[35] P. Bourdieu, "Habitus," in Habitus: A Sense of Place, J. Hillier and E. Rooksby, Eds. Aldershot: Ashgate, 2005, pp. 43-52.

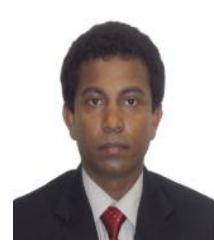

Anton Piyarathne is currently reading for his $\mathrm{Ph} . \mathrm{D}$. in Anthropology at the Macquarie University, Sydney, Australia. He obtained BA (1998) and MA (2005) in Sociology from the University of Colombo, Sri Lanka. He has also been serving as a senior lecturer at the Department of Social Studies (SSD), Open University of Sri Lanka (OUSL) since 2001. Before joining to OUSL he served as an assistant lecturer at the Department of Sociology, University of Colombo for two years (1999-2001) So far he has completed researches on the themes such as ethnic relations, social integration, peace buildings, democracy and politics, good governance, and youth related issues. He has published two books and several articles. His most recent book is Between Inner and Outer Worlds: A Sociological Analysis of Changing Social Identity of Estate Tamil Workers (ISBN 978-955-30-1366-8), published by Godage Publishers, Colombo in 2008. His first book, Changing Livelihood of Plantation Workers: A Sociological Analysis (in Sinhala) (ISBN 955-652-195-X), published by Wijesuriya Granta Kendraya, Colombo in 2005. He was awarded publication sponsorships by National Library and Documentation Services Board (NLDSB) of Sri Lanka for both these books. His joint article titled "Paying Price for Patronage: Election Violence in Sri Lanka" with Kristine Hoglund, attached to the Department of Peace and Conflict Research, Uppsala University-Sweden, in an International Journal: Commonwealth \& Comparative Politics, Volume 47, No 3, 287-307, July 2009 is highly cited one. 